\title{
PENGARUH PENDEKATAN PEMBELAJARAN DAN MOTIVASI BERPRESTASI TERHADAP HASIL BELAJAR MATEMATIKA SISWA DI SMP NEGERI MEDAN
}

\author{
Zulkarnaen Arafat Lubis ${ }^{1}$, Muhktar ${ }^{2}$ \\ Pascasarjana Universitas Negeri medan ${ }^{1,2}$ \\ Zulkarnain_arafat@yahoo.com ${ }^{l}$
}

\begin{abstract}
Abstrak: Tujuan penelitian ini untuk mengetahui: (1) perbedaan antara hasil belajar matematika siswa yang diajar dengan pendekatan pembelajaran matematika realistik (PMR) dan hasil belajar matematika siswa dengan pendekatan pembelajaran ekspositori; (2) perbedaan hasil belajar matematika yang mempunyai motivasi berprestasi tinggi dengan siswa yang mempunyai motivasi berprestasi rendah; (3) interaksi antara pendekatan pembelajaran dengan motivasi berprestasi terhadap hasil belajar matematika siswa. Metode penelitian menggunakan metode Quasi eksperimen dengan desain penelitian faktorial $2 \times 2$. Teknik analisis data menggunakan ANAVA dua jalur pada taraf signifika $\alpha=0,05$. Hasil analisis penelitian menunjukkan bahwa: (1) hasil belajar matematika siswa yang diajar dengan pendekatan pembelajaran matematika realistik $(P M R)$ lebih tinggi dari pada hasil belajar matematika siswa yang diajar dengan pendekatan pembelajaran ekspositori terdapat perbedaan yang signifikan antara hasil belajar matematika siswa yang mempunyai motivasi berprestasi tinggi dengan siswa yang mempunyai motivasi berprestasi rendah, terdapat interaksi antara pendekatan pembelajaran dan motivasi berprestasi terhadap hasil belajar matematika siswa.
\end{abstract}

Kata Kunci: pendekatan pembelajaran, motivasi berprestasi terhadap hasil belajar matematika

Abstract: The purpose of this study to determine: (1) the difference between the results of students' mathematics learning taught by realistic mathematics learning approach (PMR) and mathematics learning outcomes of students with expository approach; (2) differences in mathematics learning outcomes that have high achievement motivation in students with low achievement motivation; (3) the interaction between learning approach to achievement motivation on students' mathematics learning outcomes. The research method using Quasi experimental design with $2 \times 2$ factorial study data were analyzed using ANOVA two paths at the level signifika $=0.05$. Results of the analysis showed that: (1) the results of students' mathematics learning taught by learning approach realistic mathematics (PMR) is higher than on learning outcomes for mathematics students who are taught to approach expository there are significant differences between the results of learning mathematics students with achievement motivation high students with low achievement motivation, there is interaction between learning approach and achievement motivation on students' mathematics learning outcomes.

Keywords: approach to learning, achievement motivation on learning outcomes mathematics

\section{PENDAHULUAN}

Pelajaran matematika adalah salah satu mata pelajaran pokok dalam setiap jenjang pendidikan mulai dari pendidikan dasar, menengah sampai dengan pendidikan tinggi. Mata pelajaran ini sangat penting peranannya di setiap jenjang pendidikan, agar peserta didik memiliki kemampuan berfikir logis, analitis, sistematis, kritis, dan kreatif serta kemampuan bekerjasama. Menurut Soedjadi (2000:15) mengemukakan bahwa pendidikan matematika seharusnya memperhatikan dua tujuan, yaitu (1) tujuan yang bersifat formal, menekankan pada penataan nalar serta pembentukan kepribadian, dan (2) tujuan yang bersifat material, menekankan pada penerapan matematika dan keterampilan matematika. Dalam perkembangan peradaban modern, matematika memegang peranan penting, karena dengan bantuan matematika semua ilmu pengetahuan menjadi sempurna. Matematika merupakan sumber ilmu yang diperlukan oleh 
semua ilmu pengetahuan tanpa bantuan matematika semua ilmu dan teknologi tidak mendapat kemajuan yang berarti. Melihat pentingnya peranan matematika dalam ilmu dan teknologi serta dalam kehidupan seharihari maka matematika perlu dikuasai siswa mulai dari jenjang pendidikan dasar sampai perguruan tinggi. Untuk itu proses pembelajaran matematika perlu ditingkatkan guru sehingga siswa senang dan gemar terhadap pelajaran matematika.

Dalam Kurikulum Tingkat Satuan Pendidikan (Depdiknas 2004) menguraikan ada tujuan 4 pembelajaran matematika yaitu: (1) melatih cara berpikir dan bernalar dalam menarik kesimpulan, misalnya melalui kegiatan penyelidikan, eksplorasi, eksperimen, menunjukkan persamaan, perbedaan, konsistensi dan inkonsistensi, (2) mengembangkan aktivitas kreatif yang melibatkan imajinasi, intuisi, dan penemuan dengan mengembangkan pemikiran divergen, orisinil, rasa ingin tahu, membuat prediksi dan dugaan, serta mencoba-coba, (3) mengembangkan kemampuan memecahkan masalah, dan (4) mengembangkan kemampuan menyampaikan informasi atau mengkomunikasikan gagasan antara lain melalui pembicaraan lisan, catatan, grafik, peta, diagram, dalam menjelaskan gagasan.

Kenyataan saat ini menunjukkan bahwa pencapaian tujuan pembelajaran matematika masih belum memenuhi harapan. Hal ini dapat dibuktikan dari perolehan hasil belajar matematika melalui ujian nasional yang masih rendah. Dalam studi TIMSS (Trends in International Mathematics and Science Study) tahun 2009, rata-rata skor siswa tingkat 8 (kelas VIII SMP) di bawah rata-rata skor internasional dan berada pada ranking 32 dari 48 negara. Data ini menunjukkan bahwa peserta TIMSS kita secara umum kurang memuaskan, hal ini disebabkan peserta kita hanya mampu menyelesaikan soal-soal rutin dan kurang mampu menjawab menyelesaikan masalah aplikasi dalam matematika yang memerlukan penalaran dan ketrampilan proses. Baik hasil ujian akhir nasional maupun dari hasil-hasil penelitian menunjukkan bahwa penguasaan siswa terhadap bahan ajar matematika masih relatif rendah. Hal ini menyebabkan sebagian masyarakat merasa kecewa dan kurang puas dengan mutu pendidikan. Ketidakpuasan ini disebabkan masih adanya prestasi peserta didik pada pelajaran tertentu yang nilainya masih jauh dari yang diharapkan terutama pada pelajaran matematika.

Menurut Gagne (1997 : 12), bila anak belajar matematika terpisah dari pengalaman mereka sehari-hari, maka anak akan cepat lupa dan tidak dapat mengaplikasikan matematika. Salah satu pembelajaran matematika yang berorientasi pada matematisasi pengalaman sehari-hari dan menerapkan matematika dalam kehidupan sehari-hari adalah pembelajaran matematika realistik.

Salah satu faktor yang menentukan hasil belajar siswa adalah pendekatan pembelajaran. Untuk memperoleh hasil belajar yang sesuai dengan tujuan pembelajaran dibutuhkan kemampuan dalam memilih pendekatan pembelejaran yang tepat, sebab pendekatan pembelajaran merupakan hal pentin yang harus diperhatikan dalam suatu proses belajar mengajar. Dengan demikian pemilihan pendekatan pembelajaran yang sesuai dapat membangkitkan dan mendorong timbulnya aktifitas siswa untuk meningkatkan kemampuan dan pemahaman siswa terhadap materi pelajaran tertentu.

Pendekatan Pembelajaran Realistik (PMR) menekankan pentingnya konteks nyata yang dikenal siswa dan proses kontruksi pengetahuan matematika oleh siswa sendiri. Pendekatan Pembelajaran Matematika Realistik (PMR) merupakan suatu pendekatan yang menjanjikan dalam pembelajaran matematika. Berbagai literatur menyebutkan bahwa Pembelajaran Matematika Realistik (PMR) berpotensi meningkatkan pemahaman matematika siswa. Dalam PMR siswa tidak dipandang sebagai siswa yang tidak berpengetahuan yang harus diisi dengan ilmu pengetahauan. Sebaliknya siswa dipandang sebagai manusia yang memiliki seperangkat pengetahuan dan pengalaman yang diperoleh melalui interaksi dengan lingkungannya.

Selanjutnya, siswa juga memiliki potensi untuk mengembangkan pengetahuan tersebut bagi dirinya. Di dalam pembelajaran matematika diakui bahwa siswa dapat mengembangkan pengetahuan dan pemahaman matematika apabila diberikan ruang dan kesempatan untuk itu. Siswa dapat merekonstruksi kembali temuan-temuan dalam bidang matematika melalui kegiatan dan eksplorasi berbagai permasalahan, baik permasalahan dalam kehidupan sehari-hari (daily life problems) maupun permasalahan di 
dalam matematika sendiri (mathematical problems).

$$
\text { Dalam Pendekatan Matematika }
$$

Realistik (PMR) siswa dituntut lebih aktif dalam mengembangkan sikap pengetahuannya tentang matematika sesuai dengan kemampuan masing-masing sehingga akibatnya memberikan hasil belajar yang lebih bermakna pada diri siswa. Dengan demikian PMR merupakan pendekatan yang sangat berguna dalam pembelajaran matematika.

Untuk menumbuhkan kreativitas peserta didik, sajian materi perlu memuat berbagai ragam strategi, soal non rutin atau latihan pemecahan masalah (problem solving) meliputi memahami masalah, merancang model, memecahkan model, memeriksa hasil (mencari solusi yang layak) dan menafsirkan solusi yang diperoleh. Menurut Sabandar (2001 : 124) menyatakan bahwa untuk mendukung proses pembelajaran yang mengaktifkan siswa diperlukan suatu pengembangan materi pelajaran matematika yang difokuskan kepada aplikasi dalam kehidupan sehari-hari siswa ( masalah kontekstual) dan disesuaikan dengan tingkat kognitif siswa, serta penggunaan metode evaluasi dan berurutan.

Selanjutnya Soedjadi (2007: 36) menyatakan bahwa PMR merupakan pendekatan pembelajaran yang menyatakan bahwa matematika merupakan kegiatan manusia yang lebih menekankan aktivitas siswa untuk mencari, menemukan, dan membangun sendiri pengetahuan yang diperlukan sehingga pembelajaran menjadi terpusat pada siswa.

Dalam pendekatan ekspositori
pemahaman siswa dibangun dengan memberikan masalah kontekstual dalam bentuk soal cerita diakhiri pembelajaran sebagai aplikasi konsep matematika dalam kehidupan nyata. Pada akhir proses penyelesaian soal cerita dalam bentuk konkrit, dilanjutkan dalam bentuk simbol melalui proses pemahaman soal dengan menunjukkan apa yang diketahui,apa yang ditanyakan, dan operasi hitung apa yang diperlukan. Pendekatan pembelajaran ini mengakibatkan rendahnya pada kemampuam penalaran siswa. Beberapa hal yang menjadi ciri praktik pendidikan di Indonesia selama ini adalah pembelajaran berpusat pada guru. Guru menyampaikan pelajaran dengan ceramah atau ekspositori, sementara para siswa mencatatnya pada buku catatan. Dalam proses pembelajaran yang demikian, guru dianggap berhasil apabila dapat mengelola kelas sedemikian rupa sehingga siswa-siswa tertib dan tenang mengikuti pelajaran yang disampaikan guru. Pengajaran dianggap sebagai proses penyampaian fakta-fakta kepada para siswa. Siswa dianggap berhasil dalam belajar apabila mampu mengingat banyak fakta, dan mampu menyampaikan kembali fakta-fakta tersebut kepada orang lain, atau menggunakannya untuk menjawab soal-soal dalam ujian. Guru sendiri merasa belum mengajar kalau tidak menjelaskan materi pelajaran kepada para siswa. Guru yang baik adalah guru yang selama 2 kali 40 menit dapat menguasai kelas dan berceramah dengan suara yang lantang. Materi pelajaran yang disampaikan sesuai dengan Garis-garis Besar Program Pengajaran (GBPP) atau apa yang telah tertulis di dalam buku paket.

Dalam proses pembelajaran, motivasi berprestasi merupakan salah satu aspek dinamis yang sangat penting. Sering terjadi siswa yang kurang berprestasi bukan disebabkan oleh kemampuannya yang kurang, tetapi dikarenakan tidak adanya motivasi berprestasiuntuk belajar sehingga ia tidak berusaha untuk mengerahkan segala kemampuannya. Dengan demikian, bisa dikatakan siswa yang berprestasi rendah belum tentu disebabkan kemampuannya yang rendah pula, tetapi mungkin disebabkan oleh tidak adanya dorongan atau motivasi. Motivasi berprestasiadalah suatu keadaan yan terdapat dalam seseorang yang menyebabkan seseorang melakukan kegiatan tertentu untuk mencapai tujuan tertentu. Pengetahuan dan pemahaman tentang motivasi berprestasi pada siswa sangat bermanfaat bagi guru untuk: membangkitkan, meningkatkan, dan memelihara semangat siswa utnuk belajar sampai berhasil.

Keberhasilan kegiatan belajar sangat ditentukan intraksi antara siswa dan

Guru. Dimyati (2006) mengatakan ada 3 kondisi belajar yang dapat dijumpai pada kelompok siswa yaitu: Pristiwa pertama, siswa segan belajar karena tidak mengetahui kegunaan mata pelajaran di sekolah. Siswa ini bermotivasi berprestasirendah, karena kurang memperoleh informasi. Pristiwa kedua, motivasi berprestasi siswa menurun karena gangguan ekstern belajar. Pada kedua pristiwa tersebut, motivasi berprestasibelejar siswa menjadi lebih baik, setelah guru mengubah kondisi ekstern belajar siswa. Pristiwa ketiga siswa memiliki belajar tinggi. Siswa yang 
demikian ini umumnya mampu mengatasi ganguan dan hambatan belajarnya.

Proses pembelajaran akan berhasil manakala siswa mempunyai motivasi berprestasi dalam belajar. Oleh sebab itu guru perlu menumbuhkan motivasi berprestasi siswa. Untuk memperoleh hasil belajar yang optimal guru dituntut kreatif membangkitkan motivasi berprestasi siswa. Ketepatan pemilihan pendekatan dalam proses pembelajaran matematika dan motivasi berprestasi siswa sangat perlu diperhatikan agar tujuan pendidikan dapat tercapai. Berdasarkan keadaan objektif di atas, maka perlu dilakukan suatu penelitian tentang "Pengaruh pendekatan pembelajaran dan motivasi berprestasi terhadap hasil belajar matematika". Sebagai pembanding dari akibat aplikasi pendekatan pembelajaran tersebut

\section{METODE}

Penelitian dilaksanakan di SMP Negeri 1 Medan. Populasi dalam penelitian ini adalah seluruh siswa kelas XI IPA, yang terdiri dari 4 kelas. Kesemua populasi pada masing-masing kelas diasumsikan memiliki karakteristik yang hampir sama berdasarkan kemampuan akademik siswa, karena siswa yang duduk di masing-masing kelas disaring berdasarkan nilai rapot kelas $X$ (sepuluh) untuk mata pelajaran matematika, fisika, biologi, dan kimia yang harus memiliki rata-rata nilai ketuntasan belajar 65 .

Teknik pengambilan sampel dilakukan dengan teknik cluster random sampling, dari 2 dilihat pengaruh pendekatan pembelajaran ekspositori yang dilakukan secara bersama pada siswa kelas VIII SMP Negeri 17 dan SMP Negeri 29 Medan.

Berdasarkan latar belakang masalah, identifikasi masalah, dan pembatasan masalah, maka rumusan masalah penelitian ini adalah: (1) Apakah hasil belajar matematika siswa yang diajar dengan pendekatan pembelajaran realistik lebih tinggi daripada siswa yang diajar dengan pendekatan pembelajaran ekspositori?; (2) Amepakah hasil belajar matematika siswa yang memiliki motivasi berprestasi tinggi lebih tinggi daripada siswa yang memiliki motivasi berprestasi rendah?; dan (3) Apakah ada interaksi antara pendekatan pembelajaran dan motivasi berprestasi dalam mempengaruhi hasil belajar matematika siswa?

(dua) kelas yang telah terpilih sebagai sampel penelitian, selanjutnya melalui pengundian maka pada kelas XI IPA 1 terpilih sebagai kelas yang diajar dengan model pembelajaran masyarakat belajar, sedangkan siswa kelas XI IPA 4 terpilih sebagai kelas yang diberi perlakuan dengan model pembelajaran inkuiri.

Desain penelitian yang digunakan adalah desain faktorial $2 \times 2$, seperti terlihat pada Tabel 1. yang mengelompokkan model pembelajaran inkuiri dengan model pembelajaran masyarakat belajar terhadap gaya belajar visual dan gaya belajar auditorial.

Tabel 1. Desain Faktorial 2 x 2

\begin{tabular}{lcc}
\hline Motivasi (B) & \multicolumn{2}{c}{ Model Pembelajaran (A) } \\
\hline Tinggi (B $\left.{ }^{1}\right)$ & Realistik $\left(\mathrm{A}^{1}\right)$ & Ekspositori(A $\left.{ }^{2}\right)$ \\
Rendah $\left(\mathrm{B}^{2}\right)$ & $\mathrm{A}^{1} \mathrm{~B}^{1}$ & $\mathrm{~A}^{2} \mathrm{~B}^{1}$ \\
\hline
\end{tabular}

Keterangan :

$\mathrm{A}=$ Model pembelajaran

$\mathrm{B}=$ Motivasi berprestasi

$\mathrm{A}^{\prime} \quad=$ Model pembelajaran realistik

$\mathrm{A}^{2}=$ Model pembelajaran ekspositori

$\mathrm{B}^{1}=$ Motovasi berprestasi tinggi

$\mathrm{B}^{2}=$ Motivasi berprestasi rendah
$\mathrm{A}^{1} \mathrm{~B}^{1}=$ Hasil belajar matematika siswa yang diajar dengan menggunakan model pembelajaran realistik pada siswa dengan motivasi berprestasi tinggi

$\mathrm{A}^{1} \mathrm{~B}^{2}=$ Hasil belajar matematika siswa yang diajar dengan menggunakan model pembelajaran irealistik pada 
siswa dengan motivasi berprestasi rendah

$\mathrm{A}^{2} \mathrm{~B}^{1}=$ Hasil belajar matematika siswa yang diajar dengan menggunakan model pembelajaran ekspositori belajar pada siswa dengan motivasi berprestasi tinggi

$\mathrm{A}^{2} \mathrm{~B}^{2}=$ Hasil belajar matematika siswa yang diajar dengan menggunakan model pembelajaran ekspositori belajar pada siswa dengan motivasi berprestasi rendah

Teknik analisis data dalam penelitian ini menggunakan analisis deskriptif dan analisis inferensial. Teknik analisis deskriptif dimaksudkan untuk mendeskripsikan data penelitian meliputi mean, median, standard deviasi dan kecenderungan data. Data yang telah diperoleh selanjutnya disajikan dalam bentuk tabel distribusi frekuensi dan histogram. Teknik analisis inferensial digunakan untuk menguji hipotesis penelitian dengan menggunakan teknik analisis varians (ANAVA) dua jalur. Jika hasil penelitian menunjukkan terdapat interaksi antara model pembelajarn dengan gaya belajar, maka dilakukan uji lanjut. Uji lanjut yang digunakan pada penelitian ini adalah uji Scheffe jika $n$ tiap-tiap sel berbeda, dan uji Tuckey jika $n$ tiap-tiap sel sama. Untuk menggunakan ANAVA dua jalur perlu dipenuhi beberapa syarat yaitu: (1) data yang digunakan harus berdistribusi normal, untuk menguji normalitas data digunakan uji Liliefors, dan (2) data harus memiliki varians populasi homogen, untuk menguji homogenitas varians digunakan uji F (Fisher) dan uji Bartlet. Semua pengujian dilakukan pada taraf $\alpha=0,05$.

\section{HASIL DAN PEMBAHASAN} Hasil

Pengujian hipotesis penelitian dilakukan dengan menggunakan analisis varians faktorial 2 x 2 . Rangkuman hasil perhitungan Anava dapat dilihat pada Tabel. 2.

Tabel 2. Rangkuman Data Hasil Perhitungan Analisis Deskriptif

\begin{tabular}{|c|c|c|c|c|c|c|}
\hline $\begin{array}{l}\begin{array}{r}\text { Pendekatan } \\
\text { Pembelajaran }\end{array} \\
\text { Metivasi } \\
\text { berprestasi }\end{array}$ & & Realistik & & Ekspositori & & Total \\
\hline Tinggi & $\begin{array}{l}\mathrm{n} \\
\bar{x} \\
\mathrm{~s}\end{array}$ & $\begin{array}{l}=30 \\
=32 \\
=2,41\end{array}$ & $\begin{array}{l}\mathrm{n} \\
\bar{x} \\
\mathrm{~s}\end{array}$ & $\begin{array}{l}=30 \\
=28,12 \\
=2,84\end{array}$ & $\begin{array}{l}\mathrm{n} \\
\bar{x} \\
\mathrm{~s}\end{array}$ & $\begin{array}{l}=60 \\
=29,94 \\
=2,71\end{array}$ \\
\hline Rendah & $\begin{array}{l}\mathrm{n} \\
\bar{x} \\
\mathrm{~s}\end{array}$ & $\begin{array}{l}=30 \\
=25,84 \\
=2,95\end{array}$ & $\frac{\mathrm{n}}{\bar{x}}$ & $\begin{array}{l}=30 \\
=26,04 \\
=4,09\end{array}$ & $\begin{array}{l}\mathrm{n} \\
\bar{x} \\
\mathrm{~s}\end{array}$ & $\begin{array}{l}=60 \\
=25,94 \\
=3,54\end{array}$ \\
\hline Total & $\begin{array}{l}\mathrm{n} \\
\bar{x} \\
\mathrm{~s}\end{array}$ & $\begin{array}{l}=60 \\
=28,15 \\
=2,77\end{array}$ & $\begin{array}{l}\mathrm{n} \\
\bar{x} \\
\mathrm{~s}\end{array}$ & $\begin{array}{l}=60 \\
=26,92 \\
=3,65\end{array}$ & $\begin{array}{l}\mathrm{n} \\
\bar{x} \\
\mathrm{~s}\end{array}$ & $\begin{array}{l}=120 \\
=27,54 \\
=3,23\end{array}$ \\
\hline
\end{tabular}

Setelah data Tabel 1 diolah dengan ANAVA 2 jalur faktorial $2 \times 2$, maka diperoleh hasil analisis seperti ditunjukkan pada Tabel 3.

Tabel 3. Rangkuman Anava Faktorial 2 × 2

\begin{tabular}{|l|c|c|c|c|c|}
\hline \multicolumn{1}{|c|}{ Sumber Variasi } & $\mathbf{d k}$ & $\mathbf{J k}$ & $\mathbf{R j k}$ & $\mathbf{F}$-Hitung & $\begin{array}{c}\text { F-Tabel (1,76) } \\
(\boldsymbol{\alpha}=\mathbf{0 , 0 5})\end{array}$ \\
\hline Pendekatan Pembelajaran & 1 & 307,21 & 307,21 & 29,57 & 3,97 \\
Motivasi berprestasi & 1 & 46,01 & 46,01 & 4,43 & 3,97 \\
Interaksi & 1 & 74,59 & 74,59 & 7,18 & 3,97 \\
Galat & 76 & 790,08 & 10,39 & & \\
\hline \multicolumn{1}{|c|}{ Total } & $\mathbf{1}$ & $\mathbf{1 2 1 7 , 8 9}$ & - & & \\
\hline
\end{tabular}


Berdasarkan rangkuman di atas maka akan dirinci pengujian hipotesis sebagai berikut :

Perbedaan Hasil Belajar Matematika Antara Siswa yang Diajar dengan Pendekatan Pembelajaran Realistik dan Ekspositori

Pengujian hipotesis pertama yang berbunyi : Hasil belajar matematika siswa yang diajar dengan pendekatan pembelajaran realistik lebih tinggi daripada hasil belajar siswa yang diajarkan dengan pendekatan pembelajaran ekspositori. Hipotesis statistiknya adalah :

Ho $: \mu \mathrm{A}_{1}=\mu \mathrm{A}_{2}$

Ha $: \mu A_{1}>\mu A_{2}$

Ho $=$ Tidak terdapat perbedaan hasil belajar matematika siswa yang diajar dengan pendekatan pembelajaran relaistik dengan siswa yang diajar dengan pendekatan ekspositori.

$\mathrm{Ha} \quad=$ Siswa yang diajar dengan pendekatan pembelajaran realistik memperoleh hasil belajar yang lebih tinggi daripada siswa yang diajar dengan pendekatan ekspositori

Berdasarkan perhitungan Anava Faktorial $2 \times 2$ diperoleh $\mathrm{F}-$ Hitung $=29,57$ sedangkan nilai $\mathrm{F}-$ Tabel $=3,968$ untuk $\mathrm{dk}$ $(1,76)$ dan taraf nyata $\alpha=0,05$. Ternyata nilai $\mathrm{F}-$ Hitung $=29,57>\mathrm{F}-$ Tabel $=3,968$ sehingga pengujian hipotesis menolak Ho. Dengan demikian dapat ditarik kesimpulan bahwa hasil belajar matematika siswa yagn diajar dengan pendekatan pembelajaran realistic lebih baik dibandingkan dengan hasil belajar matematika siswa yang diajar dengan pendekatan ekspositori dapat diterima dan terbukti secara empiric. Hal ini juga terlihat dari rata-rata hasil belajar matematika siswa yang diajar dengan pendekatan pembelajaran realistic $(\bar{x}=26,12)$.

\section{Perbedaan Hasil Belajar Matematika Antara Siswa yang Diajar dengan Pendekatan Pembelajaran Realistik dan Ekspositori}

Pengujian hipotesis kedua yaitu : hasil belajar matematika siswa yang memiliki motivasi berprestasi tinggi lebih tinggi daripada hasil belajar siswa yang memiliki motivasi berprestasi tinggi. Hipotesis statistiknya adalah :

Ho: $\mu \mathrm{B}_{1}=\mu \mathrm{B}_{2}$

$\mathrm{Ha}: \mu \mathrm{B}_{1}>\mu \mathrm{B}_{2}$
Ho = Tidak terdapat perbedaan hasil belajar matematika siswa yang memilki motivasi berprestasi tinggi dengan siswa yang memiliki motivasi berprestasi rendah .

$\mathrm{Ha}=$ Hasil belajar matematika siswa yang memiliki motivasi berprestasi tinggi lebih tinggi daripada siswa yang memiliki motivasi berprestasi rendah.

Berdasarkan perhitungan Anava Faktorial 2 x 2 diperoleh $F_{\text {-Hitung }}=4,43$ sedangkan nilai $\mathrm{F}_{\text {-Tabel }}=3,968$ untuk dk $(1,76)$ dan taraf nyata $\alpha=0,05$. Ternyata nilai $\mathrm{F}$-Hitung $=4,43>\mathrm{F}_{\text {-Tabel }}=3,968$ sehingga pengujian hipotesis menolaj Ho. Dengan demikian dapat ditarik kesimpulan bahwa hasil belajar matematika siswa yang memiliki motivasi berprestasi internal lebih tinggi dari pada hasil belajar siswa yang nemiliki motivasi berprestasi rendah dapat diterima dan terbukti secara empiric. Hal ini juga terlihat dari ratarata hasil belajar matematika siswa dengan motivasi berprestasi tinggi $((\bar{x}=29,94)$ lebih tinggi dari hasil belajar matematika siswa dengan motivasi berprestasi rendah $((\bar{x}=25$, 94).

Interaksi Antara Pendekatan Pembelajaran dan Motivasi Berprestasi Terhadap Hasil Belajar

Pengujian hipotesis ketiga yaitu terdapat interaksi antara pendekatan pembelajaran dan motivasi berprestasi dalam mempengaruhi hasil belajar matematika. Hipotesis statistiknya adalah :

Ho : $\mathrm{A} X \mathrm{~B}=\mathrm{O}$

$\mathrm{Ha}: \mathrm{A} X \mathrm{~B} \neq \mathrm{O}$

Ho = Tidak terdapat interaksi antara pendekatan pembelajaran dan motivasi berprestasi terhadap hasil belajar matematika.

$\mathrm{Ha}=$ Terdapat interakasi anatara pendekatan pembelajaran dan motivasi berprestasi terhadap hasil belajar matematika.

Berdasarkan perhitungan Anava Faktorial 2 x 2 diperoleh $\mathrm{F}_{\text {-Hitung }}=7,18$, sedangkan nilai $\mathrm{F}_{\text {-Tabel }}=3,968$ untuk dk $(1,76)$ dan taraf nyata $\alpha=0,05$. Ternyata nilai $\mathrm{F}_{\text {-Hitung }}$ $=7,18>\mathrm{F}_{\text {-Tabel }}=3,968$ sehingga pengujian hipotesis menolak Ho. Dengan demikian dapat ditarik kesimpulan bahwa terdapat interaksi 
antara pendekatan pembelajaran dan motivasi control dalam mempengaruhi hasil belajar matematika dapat diterima dan terbukti secara empiris.

Untuk mengetahui perbedaan antara pendekatan pembelajaran dan motivasi berprestasi terhadap hasil belajar matematika, maka dilakukan uji lanjut dengan uji Scheffe. Rangkuman perhitungan uji Scheffe adalah sebagai berikut :

Tabel 4. Rangkuman Uji Tukey

\begin{tabular}{|c|c|c|c|}
\hline \multicolumn{2}{|c|}{ HIPOTESIS STATISTIK } & F- Hitung & $\begin{array}{c}\text { F-Tabel (3,76) } \\
(\boldsymbol{\alpha}=\mathbf{0 , 0 5})\end{array}$ \\
\hline Ho $: \mu 11=\mu 12$ & $\mathrm{Ha}: \mu 11=\mu 12$ & 4,03 & 3,97 \\
\hline Но $: \mu 11=\mu 21$ & $\mathrm{Ha}: \mu 11=\mu 21$ & 5,60 & 3,97 \\
\hline Но $: \mu 11=\mu 22$ & $\mathrm{Ha}: \mu 11=\mu 22$ & 5,27 & 3,97 \\
\hline Но $: \mu 12=\mu 21$ & $\mathrm{Ha}: \mu 12=\mu 21$ & 5,26 & 3,97 \\
\hline Но $: \mu 12=\mu 22$ & $\mathrm{Ha}: \mu 12=\mu 22$ & 6,60 & 3,97 \\
\hline Но $: \mu 21=\mu 22$ & $\mathrm{Ha}: \mu 21=\mu 22$ & 5,23 & 3,97 \\
\hline
\end{tabular}

Dari hasil Uji scheffe diperoleh kesimpulan yaitu : (1) rata-rata hasil belajar matematika siswa yang memiliki motivasi berprestasi tinggi yang diajar dengan menggunakan pendekatan pembelajaran realistik lebih tinggi dari siswa yang memiliki motivasi berprestasi tinggi yang diajar menggunakan pendekatan pembelajaran ekspositori, (2) rata-rata hasil belajar matematika siswa yang yang memiliki motivasi berprestasi rendah yang diajar dengan pendekatan pembelajaran realistik sama dengan hasil belajar matematika siswa yang yang memiliki motivasi berprestasi rendah yang diajar dengan pendekatan ekspositori, (3) rata-rata hasil belajar matematika siswa yang memiliki motivasi berprestasi tinggi yang diajar menggunakan pendekatan pembelajaran realistik lebih tinggi dari siswa yang yang memiliki motivasi berprestasi rendah yang diajar dengan pendekatan pembelajaran realistik, (4) rata-rata hasil belajar matematika siswa yang memiliki motivasi berprestasi tinggi yang diajar dengan pendekatan pembelajaran ekspositori lebih tinggi dari hasil belajar siswa yang memiliki motivasi berprestasi rendah yang diajar denan pendekatan pembelajaran ekspositori, (5) ratarata hasil belajar matematika siswa yang memiliki motivasi berprestasi tinggi yang diajar dengan pendekatan pembelajaran realistik sama dengan rata-rata hasil belajar siswa yang memiliki motivasi berprestasi rendah yang diajar dengan pendekatan pembelajaran ekspositori, dan (6) rata-rata hasil belajar matematika siswa yang memiliki motivasi berprestasi tinggi yang diajar dengan pendekatan ekspositori sama denggan hasil belajar matematika siswa yang memiliki motivasi berprestasi rendah yag diajar dengan pendekatan pembelajaran realistik.

Berdasarkan simpulan uji scheffe di atas diperoleh data bahwa pada simpulan pertama rata-rata hasil belajar matematika siswa yang memiliki motivasi berprestasi tinggi yang diajar dengan menggunakan pendekatan pembelajaran realistik lebih tinggi dari pada siswa yang memiliki motivasi berprestasi tinggi yang diajar dengan menggunakan pendekatan pembelajaran ekspositori, ini berarti bahwa pada siswa yang memiliki motivasi berprestasi tinggi lebih baik belajar menggunakan pendekatan PMR. Simpulan ini diperoleh berdasarkan data bahwa Fh $(4,21)>$ Ft $(3,97)$ untuk $\alpha=5 \%$, data ini menunjukan perbedaan pendekatan pembelajaran antara siswa yang memiliki motivasi berprestasi tinggi dengan siswa yang memiliki motivasi berprestasi rendah memberikan pengaruh secara signifikan terhadap hasil belajar matematika.

Pada simpulan kedua diperoleh ratarata hasil belajar matematika siswa yang berjeis kelamin perempuan yang diajar dengan pendekatan pembelajaran realistik sama dengan hasil belajar matematika siswa yang yang memiliki motivasi berprestasi rendah yang diajar dengan pendekatan ekspositori, kesimpulan ini diperoleh berdasarkan data bahwa Fh $(1,35)<\mathrm{Ft}(3,97) \alpha=5 \%$, data ini menunjukkan bahwa pada siswa yang memiliki motivasi berprestasi rendah kedua pendekatan yang diberikan tidak berpengaruh secara signifikan terhadap hasil belajar matematika. 
Simpulan ketiga diperoleh simpulan rata-rata hasil belajar matematika siswa yang memiliki motivasi berprestasi tinggi yang diajar menggunakan pendekatan pembelajaran realistik lebih tinggi dari siswa yang yang memiliki motivasi berprestasi rendah yang diajar dengan startegi pembelajaran berbasis masalah, hal ini juga membuktikan bahwa pendekatan PMR baik digunakan pada siswa yang memiliki motivasi berprestasi tinggi karena dengan pendekatan ini hasil belajar siswa lebih tinggi, simpulan ini diperoleh berdasarkan data bahwa Fh $(2,80)>\mathrm{Ft}(3,97)$ untuk $\alpha=5 \%$, data ini menunjukkan perbedaan pendekatan pembelajaran yan diberikan pada motivasi berprestasi yang berbeda memberi pengaruh yang signifikan terhadap hasil belajar matematika.

Pernyataan simpulan keempat adalah rata-rata hasil belajar matematika siswa yang memiliki motivasi berprestasi tinggi yang diajar dengan pendekatan pembelajaran ekspositori lebih tinggi dari hasil belajar siswa yang memiliki motivasi berprestasi rendah yang diajar dengan pendekatan pembelajaran ekspositori, pernyataan ini sekali lagi membuktikan bahwa hasil belajar matematika siswa laki-laki lebih tinggi dari pada hasil belajar matematika siswa yang memiliki motivasi berprestasi tinggi meskipun samasama di berikan pendekatan pembelajaran ekspositori, simpulan ini dirperoleh berdasarkan data bahwa Fh $(3,09)>\mathrm{Ft}(3,97)$ untuk $\alpha=5 \%$, data ini menunjukkan pendekatan pembelajaran ekspositori yang diberikan pada motivasi berprestasi yang berbeda memberi pengaruh yag signifikan terhadap hasil belajar siswa.

Pada simpulan kelima diperoleh ratarata hasil belajar matematika siswa yang memiliki motivasi berprestasi tinggi yang diajar dengan pendekatan pembelajaran realistik sama denan rata-rata hasil belajar matematika siswa yang memiliki motivasi berprestasi rendah yang diajar dengan pendekatan pembelajaran ekspositori. Ini membuktikan bahwa pendekatan pembelajaran PBM yang diberikan pada siswa laki-laki dan pendekatan ekspositori yang diberikan pada siswa perempuan tidak memberikan pengaruh perbedaan hasil belajar matematika, simpulan ini diperoleh berdasarkan data bahwa Fh $(1,50)$ $<$ Ft $(3,97)$ untuk $\alpha=5 \%$, data ini menunjukkan startegi pembelajaran yang berbeda dan diberikan pada motivasi berprestasi yang berbeda tidak memberi pengaruh yang signifikan terhadap hasil belajar matematika.

Simpulan keenam diperoleh rata-rata hasil belajar matematika siswa yang memiliki motivasi berprestasi tinggi yang diajar dengan pendekatan ekspositori sama dengan hasil belajar matematika siswa yang memiliki motivasi berprestasi rendah yang diajar dengan pendekatan pembelajaran realistik, dengan demikian rata-rata hasil belajar siswa dengan motivasi berprestasi tinggi yang diajar dengan pendekatan ekspositori secara signifikan tidak jauh berbeda dengan rata-rata hasil belajar siswa dengan motivasi berprestasi rendah yang diajar dengan pendekatan PMR, simpulan ini diperoleh berdasarkan data bahwa Fh $(1,83)<$ Ft $(3,97)$ untuk $\alpha=5 \%$ data ini menunjukkan pendekatan pembelajaran yang berbeda dan diberikan pada motivasi berprestasi yang berbeda tidak memberi pengaruh yan signifkan terhadap hasil belajar matematika.

Hasil pengujian hipotesis diatas, menunjukkan adanya interaksi antara pendekatan pembelajaran dan motivasi berprestasi terhadap hasil belajar matematika. Interaksi antara pendekatan pembelajaran tersebut dapat divisualisasikan secara grafis pada gambar berikut. 


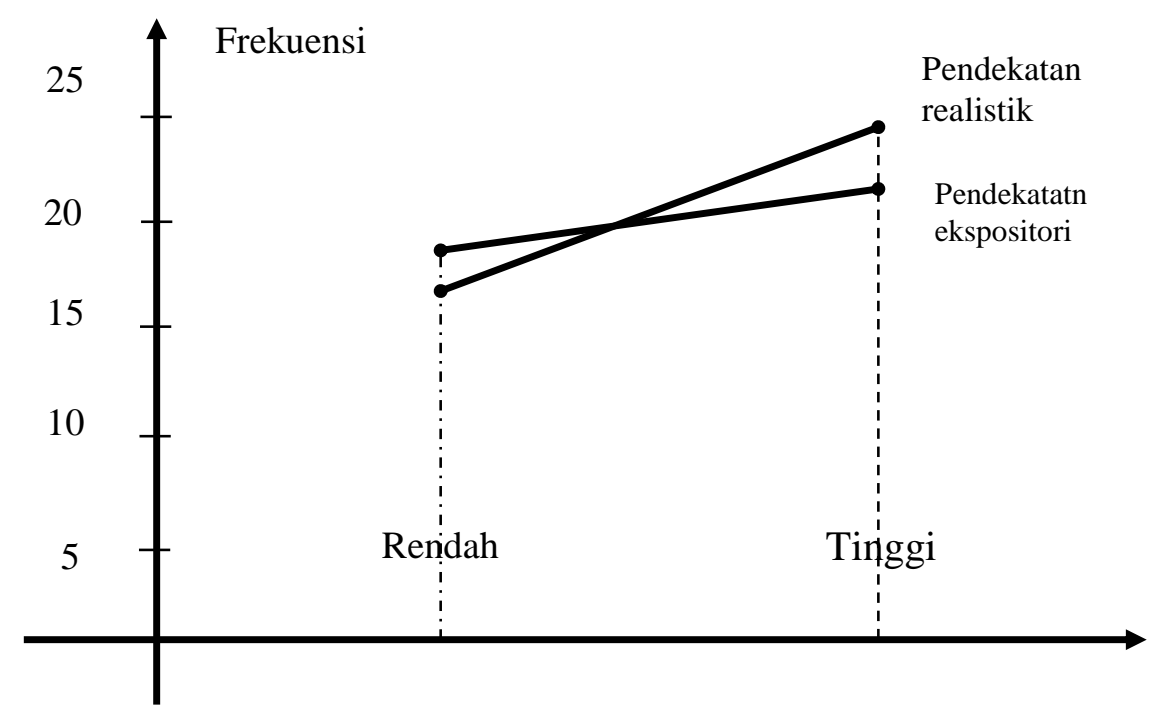

Gambar 1. Interaksi Antar Pendekatan Pembelajaran dan Motivasi Berprestasi Terhadap Hasil Belajar Matematika

Berdasarkan hasil pengujian hipotesis ketiga yang menyatakan adanya interkasi antara pendekatan pembelajaran dengan perbedaan motivasi berprestasi, maka perlu dilakukan uji peerbedaan rata - rata anatara dua proporsi. Gambar di atas terlihat adanya interaksi antara pendekatan pembelajaran dengan motivasi berprestasi terhadap hasil belajar matematika.

\section{Pembahasan}

Dari hasil pengolahan data yang dilakukan terdapat perbedaan hasil belajar matematika antara siswa yang diajar dengan pendekatan pembelajaran PMR dengan pendekatan pembelajaran ekspositori, yaitu rata-rata hasil belajar matematika siswa yang diajar dengan pendekatan pembelajaran PMR lebih tinggi dari pada rata-rata hasil matematika siswa yang diajar dengan pendekatan pembelajaran ekspositori. Kenyataan ini membuktikan bahwa pendekatan pembelajaran PMR lebih baik dalam meningkatkan pemahaman siswa dalam pembelajaran matematika daripada penggunaan pendekatan pembelajaran ekspositori.

Hasil penelitian menunjukkan bahwa rata-rata hasil belajar matematika siswa yang memiliki motivasi berprestasi tinggi akan lebih mudah meningkatkan pengetahuan, pemahaman dan penguasannya terhadap setiap materi yang di pelajari, karena keinginan mereka untuk mau dan mampu belajar sehinga merasa perlu untuk memahami materi pembelajaran matematika hal ini memungkinkan siswa tersebut memperoleh hasil belajar matematika yang lebih baik pula.

Berdasarkan hasil penelitian ternyata perbedaan motivasi berprestasi mempengaruhi hasil belajar matematika siswa,

Temuan penelitian menunjukkan bahwa terdapat interaksi antara pendekatan pembelajaran dan perbedaan motivasi berprestasi terhadap hasil belajar matematika siswa. Siswa yang bermotivasi berprestasi tinggi dengan mengikuti pendekatan pembelajaran PMR lebih tinggi hasil belajarnya dibandingakan dengan siswa bermotivasi berprestasi rendah dengan pendekatan pembelajaran ekspositori. Demikian pula siswa yang bermotivasi berprestasi rendah dengan mengikuti pendekatan pembelajaran ekspositori memperoleh hasil belajar yang lebih tinggi, dibandingkan dengan siswa yang bermotivasi berprestasi tinggi dengan pendekatan pembelajaran ekspositori. Hal ini mengindikasikan adanya interaksi antara pendekatan pembelajaran dengan motivasi berprestasi siswa terhadap hasil belajar matematika.

Mata pelajaran matematika merupakan mata pelajaran yang mengharuskan siswa memilki sejumlah kompetensi khususnya dalam pemahaman konsep,aplikasi sains, dan kinerja ilmiah. Kemampuan ini akan lebih mudah diperoleh oleh siswa yang memiliki motivasi berprestasi tinggi cenderung suka dalam menemukan sesuatu hal yang baru yang 
berkaitan dengan penemuan melalui prosedur ilmiah. Sikap ini akan lebih berkembang jika siswa aktif belajar secara lansung melalui langkah-langkah metode ilmiah dengan penemuan layaknya seorang ilmuan melalui PMR. Untuk siswa yang bermotivasi berprestasi rendah, pembelajaran matematika lebih baik jika diajar dengan pendekatan pembelajaran ekspositori dibandingkan menggunakan pendekatan pembelajaran PMR. Hal ini mungkin disebabkan karena pendekatan pembelajaran ekspositori cenderung menggunakan langkah-langkah atau konsep yang telah ditetapkan oleh guru dan lebih berpengaruh ke aspek ingatan dan pemahaman yang langsung yang dirasakan oleh siswa bermotivasi berprestasi rendah.

Meskipun pendekatan pembelajaran realistik baik digunakan pada siswa dengan motivasi berprestasi tinggi, namun tidak tertutup kemungkinan pendekatan pembelajaran realistik ini juga dapat digunakan pada siswa dengan motivasi berprestasi rendah. Hal ini dikarenakan persoalan yang muncul melatih siswa untuk bekerjasama dan sehingga mampu memotivasi siswa dalam menggeluti matematika sesuai dengan kopetensi yang diharapkan dari mata pelajaran matematika, khususnya pada siswa SMP.

Berdasarkan hasil belajar matematika siswa secara keseluruhan, terjadi peningkatan rata-rata hasil belajar siswa sebelum perlakuan dan sesudah perlakuan, khususnya pada kelas perlakuan dengan pendekatan pembelajaran PMR. Sedangkan pada kelas perlakuan dengan pendekatan pembelajaran ekspositori, meski terjadi peningkatan rata-rata hasil belajar, namun peningkatan rata-rata hasil pembelajaran yang selama ini dilaksanakan di lokasi penelitian sebelum penelitian dilaksanakan. Jika sebelum perlakuan pada kelas PMR maupun kelas ekspositori nilai ratarata harian siswa dalam setiap kali pertemuan hanya berkisar 65 sampai 70, namun setelah dilaksanakan perlakuan terjadi peningkatan hasil belajar rata-rata siswa antara 75 sampai 90.

\section{PENUTUP}

Berdasarkan pembahasan yang telah diuraikan di atas maka dapat ditarik beberapa simpulan sebagai berikut :

1. Hasil belajar matematika siswa SMP Negeri Medan yang diajar dengan pendekatan pembelajaran realistik (RME) lebih baik daripada hasil belajar matematika siswa yang diajar dengan pendekatan pembelajaran ekspositori.

2. Hasil belajar matematika siswa yang mempunyai motivasi berprestasi tinggi lebih baik daripada hasil belajar matematika siswa yang mempunyai motivasi berprestasi rendah.

3. Terdapat interaksi antara strategi pembelajaran dengan motivasi berprestasi dalam memberikan pengaruh terhadap hasil belajar matematika siswa di SMP Negeri Medan, siswa yang mempunyai motivasi berprestasi tinggi lebih baik diajar dengan pendekatan pembelajaran realistik (RME), sedangkan siswa yang mempunyai maotivasi berprestasi rendah lebih baik diajar dengan pendekatan pembelajaran ekspositori.

\section{DAFTAR PUSTAKA}

Angkowo, R. (2007). Optimalisasi Media Pembelajaran. Jakarta : Grasindo

Ansari, I. Bansu. (2009), Komunikasi Matematik Konsep dan Aplikasi. Banda Aceh : Yayasan Pena

Arikunto, S. (2006). Prosedur Penelitian Suatu Pendekatan Praktik. Jakarta : Rineke Cipta

Arikunto, S. ( 2008 ).Dasar-Dasar Evaluasi Pendidikan. Jakarta :Bumi Aksara.

Armanto,D. (2003) Pengembangan alur pembelajaran lokal topik perkalian dan pembagian di dua kota yang berbeda yaitu Yogyakarta dan Medan dengan pendekatan Matematika Realistik menunjukkan bahwa siswa belajar dengan aktif.

Atmodiwirio, S. ( 2002$)$ Menajemen Pelatihan. Jakarta : PT. Ardadizya Jaya

Aunurrahman. (2009). Belajar dan Pembelajaran. Bandung : Alfabeta

Bloom, B.S.(1997).Human Charadteristic and school Learning. New York : McGrawHill Book Company.

Brannen, J. (2005). Memadu Metode Penelitian Kualitatif \& kuantitatif. Samarinda : Fakultas Tarbiyah IAIN Antasari Samarinda

Dahar, R.W. (1998), Teori-teori belajar, Jakarta, Penerbit Erlangga.

Dharby (2002), Pembelajaran Matematika untuk Mendukung Pelaksanaan Kurikulum Berbasis Kompetensi, 
Makalah pada Pelatihan Guru MTs Bandung

Depdiknas (2004). Kurikulum Tingkat Satuan Pendidikan. Jakarta : Pusat Kurikulum Departemen Pendidikan Nasional.

Depdiknas (2003). Undang-undang Standar Penelitian Nasional. Jakarta : Departemen Pendidikan Nasional.

Dick, W. \& Carey, L. (2005), The systematic design of instruction, Florida: Harper Callins Publisher.

Djamarah, S.B. dan Zein. (2006), Strategi belajar mengajar, Jakarta : Rineka Cipta,

Fauzan, Ahmad.(2002)."Applying mathematics Education (RME) in Teaching Geometri in Indonesian Primary Schools". Dissertation, University of Twente, The Netherlands.

Gerlach,V.S\&Ely,D.P.(1980) Teaching and Media : a systematic Approach. New York: Prentice Hall Inc.

Gravemeijer (1994). Developing Realistic Mathematics Education. Utrecht: CD-b Press. The Netherlands

Hadi, S. (2005). Pendidikan Matematika Realistik. Banjarmasin: penerbit Tulip

Hamalik, O. (2008), Perencanaan pengajaran Berdasarkan Pendekatan Sistem , Jakarta, Bumi Aksara.

Harjanto. (2 008). Perencanaan Pengajaran. Jakarta: Rineka Cipta.

Hasibuan,J.J. (2008). Proses Belajar Mengajar. Bandung: Remaja Rosdakarya.

Jihad, A. (2008). Pengembangan Kurikulum Matematika. Yogyakarta: Multi Pressindo

Maslow's, A. (2000), Hierarchy of needs, http:/www.geogle.com. (Diakses 28 Juni 2011).

Merril,M.David(1979).Instructional Design Theory.New Jersey:Englewood Cliffs

Miarso, Y, dkk. (2007). Menyemai Benih Teknologi Pendidikan. Jakarta : Prenada Media.

Nasution, S. (2008). Berbagai Pendekatan dalam Proses Belajar \& Mengajar. Jakarta : Bumi Aksara
Nazir, Moh. (2003). Metode Penelitian. Jakarta: Ghalia Indonesia

Pepak. (2008). Masalah Motivasi berprestasi. http//www.Pepak.sabda.org.

Pidarta, M. (2000), Landasan kependidikan, Jakarta, Rineka Cipta.

Ratini (2005) Pembelajaran Pecahan Dengan Pendekatan Pendidikan Matematika Realistik Indonesia (PMRI) Di Kelas III MIN Yogyakarta II.

Reigeluth, C.M. (1983), Instructional design theories and models, an observiews of their current states, London, Lawrence Earl Baum Assocates.

Romizwoski, A. J. (1981). Designing Instructional System, London: Kongen Page Ltd

Sanjaya,W. (2008). Perencanaan dan Desain Sistem Pembelajaran. Jakarta : Kencana Prenada Media Group.

Sudjana,N. (2005). Penilaian Hasil Proses Belajar Mengajar. Bandung: Remaja Rosdakarya

Soedjadi, R. 2000. Kiat Pendidikan Matematika di Indonesia, (konstatasi keadaan masa kinimenuju harapan masa depan). Direktorat Jenderal Pendidikan Tinggi. Depdiknas.

Sukmadinata, N.S. dkk (2006). Pengendalian Mutu Pendidikan Sekolah Menengah (Konsep, Prinsip, dan Instrumen). Bandung: Refika Aditama

Sukmadinata, N.S. (2008). Pengembangan Kurikulum. Bandung : PT. Remaja Rosdakarya.

Suparman, A.M. (2001). Desain Instruksional. Jakarta : Universitas Terbuka

Syamsudin M.A. (2003). Belajar Kependidikan perangkat sistem pengajaran modul. Bandung. Rosdakarya.

Turmudi. (2008). Landasan Filsafat dan Teori Pembelajaran Matematika. Jakarta: Leuser Cita Pustaka.

Uno, H.B. (2008). Teori motivasi berprestasidan pengukuran. Jakarta. Bumi Aksara.

Winataputra, H. U. S. (2001). Strategi belajar mengajar. Jakarta. PPUT. 